IZA DP No. 8034

Wage Determination and Imperfect Competition

Alison Booth

March 2014 


\title{
Wage Determination and Imperfect Competition
}

\author{
Alison Booth \\ Australian National University \\ and IZA
Discussion Paper No. 8034
March 2014

\author{
IZA \\ P.O. Box 7240 \\ 53072 Bonn \\ Germany \\ Phone: +49-228-3894-0 \\ Fax: +49-228-3894-180 \\ E-mail: iza@iza.org
}

Any opinions expressed here are those of the author(s) and not those of IZA. Research published in this series may include views on policy, but the institute itself takes no institutional policy positions. The IZA research network is committed to the IZA Guiding Principles of Research Integrity.

The Institute for the Study of Labor (IZA) in Bonn is a local and virtual international research center and a place of communication between science, politics and business. IZA is an independent nonprofit organization supported by Deutsche Post Foundation. The center is associated with the University of Bonn and offers a stimulating research environment through its international network, workshops and conferences, data service, project support, research visits and doctoral program. IZA engages in (i) original and internationally competitive research in all fields of labor economics, (ii) development of policy concepts, and (iii) dissemination of research results and concepts to the interested public.

IZA Discussion Papers often represent preliminary work and are circulated to encourage discussion. Citation of such a paper should account for its provisional character. A revised version may be available directly from the author. 


\title{
ABSTRACT \\ Wage Determination and Imperfect Competition
}

\begin{abstract}
A striking feature of the past few decades has been the development of wage-determination models that assume that labour markets are imperfectly competitive. This paper discusses two such models (trade unions and oligopsony), although there are many more. It also asks if imperfectly competitive models should be used whenever researchers are modelling the labour market. Some people would argue for this only in cases when the predictions and comparative statics of the imperfectly competitive model differ from those of the competitive model. Of course, to know this, one needs to know precisely what the predictions and comparative statics of the respective models are. Moreover, for policymakers to be able to determine if an intervention is required in the first place, there does need to be some analytical framework to act as a guide. In the perfectly competitive model of the labour markets, for example, typically no intervention or regulation would be justified. However, labour economics has moved far beyond this position, with the incorporation of new ideas into modeling wage determination in imperfectly competitive labour markets, and with the availability of better datasets to facilitate empirical investigation.
\end{abstract}

JEL Classification: J2, J3, J5, D4

Keywords: wage determination, oligopsony, trade unions, imperfect competition, labour markets

Corresponding author:

Alison L. Booth

Research School of Economics

College of Business and Economics

HW Arndt Building 25a

Australian National University

ACT 0200

Australia

E-mail: alison.booth@anu.edu.au

\footnotetext{
* Paper prepared for the $20^{\text {th }}$ anniversary issue of Labour Economics and the $25^{\text {th }}$ anniversary celebration of the European Association of Labour Economists (EALE), held in Turin in September 2013. Thanks to Joop Hartog for his helpful suggestions, and also to my discussant Bernd Fitzenberger.
} 


\section{Introduction}

How have labour economists' perspectives about theories of wage determination altered over the past quarter of a century? In this anniversary issue of Labour Economics, celebrating 20 years since the journal's inception and 25 years since the establishment of the European Association of Labour Economists, it seems particularly appropriate to consider this question.

It would be fair to say that even a quarter of a century ago many economists viewed the labour market as intrinsically perfectly competitive. Of course there were earlier exceptions to this perfectly competitive approach. From our 2014 vantage point, two examples seem especially insightful. These are Joan Robinson's 1933 monopsony theory and Alfred Marshall's summary of the features of labour that distinguish it from other inputs.

There are a number of different models of wage determination in the labour economics literature, all deviating from perfect competition in various ways. These include search theory, efficiency wages, and others, some of which are covered in this volume. Here I shall look only at two. These are my own personal favourites, partly because they can be viewed as representing two polar extremes but also because they are intuitively appealing and tractable. The first considers a situation with few sellers of labour (wage determination under trade unions), while the second considers a situation in which there are few buyers (wage determination under oligopsony).

In the 20th-century no analyst of the labour market could have failed to be aware of the importance of trade unions. These were typically viewed as operating 
within an otherwise perfectly perfectly competitive labour market, and having harmful effects on the economy through their control over the supply of labour. This monopoly power forced up wages, generating rents for those workers fortunate enough to be in employment, and causing allocative inefficiencies. The magnitude of these rents depended crucially on the elasticity of labour demand. The more elastic was labour demand the smaller the size of any surplus that could be appropriated.

While there were some rare dissenting voices claiming that trade unions could in some instances be efficiency-enhancing, the dominant opinion in the late 1970s was that they caused allocative inefficiencies.

From the late 1970s through to the 1990s there was a tremendous growth in the economics of the trade union. This focused on the wage-setting behavior of unions as well as measuring their impact on other outcomes. Initially the models viewed trade union behaviour as a modification of perfect competition in which trade unions represented workers and were characterised by monopoly power. As the years rolled by, the notion that workers possess monopoly power and expropriated all the surplus gave way to the idea that the surplus might be shared between union workers and the firm. Insights from bargaining theory were employed to show how this would be managed. It came as no surprise that the share each party received depended on their relative bargaining power. Moreover the size of the surplus also mattered. And in time it became clear that the size of the surplus was positively related to the degree of imperfect competition in the product market. 
Paralleling these developments in theories of union wage determination and employment were innovations in macroeconomic thinking. Here researchers were beginning to utilise models of, for instance, monopolistic competition to explain how small adjustment costs could give rise to large business cycle fluctuations that could happen without any trade union presence. Increasingly labour economists began to take on board these ideas. Other approaches, such as heterogeneous job characteristics that Salop (1979) incorporated into the theory of the firm, were also to filter into labour economics.

Perhaps the most interesting development in wage determination theories of the past decade or so has been the realization that employers have some market power in wage-setting. ${ }^{1}$ This is not only a plausible and reasonably tractable characterization of the labour market, but it can also help explain certain labour market phenomena. An early example of an oligopsonistic competition model is that of Stevens (1994). Another example is Bhaskar and To (1999), who assume asymmetric information in analyzing the impact of minimum wages. Their starting point was that workers have idiosyncratic preferences over employment at different firms, and that these preferences are private information. Manning (2003) further develops this in the context of other characterisations (including search theory which is the subject of Pierre Cahuc's paper in this special issue.)

There are a number of other sources of rents in the employment relation. Not only do individuals have heterogeneous preferences for jobs, but they also have

\footnotetext{
${ }^{1}$ Of course this had been realized by many economists years earlier, but the idea has only relatively recently been embraced more widely by labour economists.
} 
differences in mobility costs and they face imperfect information. Because of this, it takes time for a worker to find an alternative employer who is a perfect substitute for her current one. Moreover it is expensive for the firm to find another worker who is perfectly substitutable for his current one. This heterogeneity, and search and mobility costs, imply that there are rents in the employment relationship.

The remainder of the paper is set out as follows. Section 2 describes the perfectly competitive benchmark. Section 3 is devoted to wage determination under trade unions. There has been a dramatic decline in research in this area since the early 2000s. I shall discuss whether this happened because of fashion or irrelevance, and will argue that unions remain relevant but that fashion has moved away. In Section 4, I shall explore wage determination under oligopsonistic competition. This is currently flavor of the decade and I shall give reasons why. In the penultimate section I shall examine where imperfect competition/monopsony theory and trade union economics have helped us better understand wage determination and the workings of labour markets.

This paper gives only a brief overview. It is not a survey of all the wage determination literature nor does it touch on the extensive empirical literature on wages and wage inequality. Rather, it simply presents my own view, an idiosyncratic one perhaps, but all as requested by the founding editors of Labour Economics, Joop Hartog and Jules Theeuwes. It is to Jules' memory that I dedicate this paper.

\section{The perfectly competitive labour market}


Perfectly competitive markets are described in economic theory as those in which no participants (buyers or sellers) have the market power to set the price of a homogeneous product. The conditions for perfect competition are strict; for example, an infinite number of agents, no barriers to entry or exit, perfect factor mobility, perfect information, no transactions costs. While the assumptions underlying perfect competition might sometimes be applicable for auction markets for certain commodities, they are rather less applicable for labour markets.

Labour has several features that distinguish it from other inputs, and that mean that labour markets cannot be in quite the same way as the markets for other factor inputs (Marshall, 1948). The two principal distinguishing characteristics of labour are first that workers retain ownership of their human capital (in the absence of slavery) and secondly that workers must be present at the workplace for the delivery of their skills. The fact that workers retain ownership of their human capital has the implication that any education or skills associated with employment are the property of the worker, who can therefore exercise some control over the use of the skills, and perhaps extract any surplus associated with them. The fact that workers must be present for the delivery of their skills means that they must live near the workplace. ${ }^{2}$ This may constrain the opportunities of other family members, and make workers vulnerable to opportunistic behaviour. (We shall return to this point in the section on oligopsonistic competition below.) This embodiment of human capital within a person also means that the social aspects of the work environment are important.

\footnotetext{
${ }^{2}$ This may well change in the future in occupations in which homeworking may become more feasible.
} 
In spite of these caveats, perfect competition may sometimes serve as a useful benchmark against which to measure imperfectly competitive labour markets and also to measure allocative inefficiency. However, once one accepts that there are rents in the employment relationship, then there is more of a role for policy.

\section{Wage determination under trade unions}

\subsection{Do trade unions still matter?}

Although the bargaining models used in trade union theory have wider application than to unionized labour markets, I shall confine my discussion here to trade unions and union wage-setting. The reader may well ask why. After all, we regularly read in the media about the declining power of trade unions, so should we as labour economists forget about the union wage-setting models? In my opinion we should not. This is not only because the modeling framework is applicable to other nonunion situations, but also because union power is not declining across OECD countries to the extent suggested by the union membership figures alone.

\section{[Insert Table 1 near here]}

While in 1990 trade union density averaged 40.1\% across OECD countries, by 2009 it had declined to $28.5 \% .^{3}$ (Trade union density refers to the number of trade union members as a percentage of wage and salary earners.) This is indeed a large drop, but the averages conceal an extraordinary degree of heterogeneity across countries, as inspection of Table 1 reveals. For example, of the 28 countries listed in the table, six

\footnotetext{
${ }^{3}$ The figures given in this paper come from the OECD database on trade unions and Visser (2011).
} 
have union density exceeding 50 percent, and four have union density exceeding two thirds (these are Denmark, Finland, Iceland and Sweden). On the other hand, fourteen countries have union density of less than one-fifth of the workforce. Can we conclude from this that unions are a dead institution? I think the answer is no. Union presence is still very important for some countries, especially European ones.

For European countries and Australia and New Zealand, the influence of trade unions at the macroeconomic level is better indicated by the extent of collective bargaining coverage of the work force, rather than by union density. (The definition of the collective bargaining coverage rate, or coverage rate for short, is the number of workers covered by wage bargaining agreements as a proportion of all wage and salary earners.) Across OECD countries, union coverage averaged $70 \%$ in 1990 and declined to $62 \%$ two decades later.

France provides an interesting example of how misleading focusing on union membership alone can be. With just under 8 percent of the workforce union members, nonetheless union coverage is high, at 90 percent. Clearly a lot of French workers are taking a free ride on union membership. Elsewhere I and others have argued that union coverage is arguably a better measure of union influence than density, and that the level at which union bargaining occurs is also important (see for example Booth, 1995; Boeri at al, 2001, and Fitzenberger et al., 2013).

However, there are still some countries in Table 1 in which both density and coverage are low. For example, in the US only 11 percent of the workforce belong to a union and only 14 percent are covered by union collective bargaining. Mexico is 
another example of a low coverage country. Britain has union density of 26 percent and coverage of 33 percent. Given that union density is declining in most industrialised countries, and that in many countries only a minority of the workforce is covered by unions, do we really need to worry about providing appropriate models of trade union behaviour? Or might we be better advised to adhere to other theories of wage setting and worker behaviour?

One answer, which we mentioned above, is that union bargaining models are generalizable and hence more widely applicable. Not only may they characterise explicit labour contracts between the union and management, but the models are also relevant to a broader class of situations than those in which a union explicitly represents workers. $^{4}$

Moreover trade union influence in a particular economy extends beyond the direct measure of union power suggested by the union density and coverage figures. For example - and this is especially appropriate to the US institutional framework - the threat of union organisation of a non-union sector may provoke management to provide wages and working conditions that mimic those negotiated in union firms. The idea is that the non-union workers will be less prone to unionise therefore, because there is little difference between their welfare in the union firm and another non-union firm providing matching benefits. Furthermore, modelling the behaviour of trade union in partially unionised economies is obviously of importance for sectoral analysis of the

\footnotetext{
${ }^{4}$ Indeed, union contracts may be viewed simply as an explicit formulation of a wider variety of labour contracts that are found in many labour markets. Where nonunion firms face an incumbent workforce with a degree of bargaining power, management and workers may be in a situation of bilateral monopoly that can be characterized by a union-firm bargaining model (Booth, 1995).
} 
parts of the economy that are heavily unionised or where a powerful sector is unionised, and there are knock-on effects for the rest of the economy through particular institutional aspects of wage setting. In addition, the threat of union organisation may provoke management into directing resources into anti-union activities and resource allocation in the non-union sector unless be indirectly affected by trade unions (Pencavel, 1991).

Why has labour economists' interest in trade unions declined in spite of the fact that trade unions are still important agents in many OECD countries? Is it due to fashion? Or does it perhaps reflect irrelevance - to the largest and most powerful economy, the US of trade unions? The answer is probably a bit of both. The US dominates research agendas with its prestigious journals and its huge population. And unions are extremely weak in the US: trade union coverage was in 2008 only $13.6 \%$, having declined from $18.3 \%$ in 1990 , while US union density was a mere $15.5 \%$ in 1990 and dropped to $11.4 \%$ in 2010.

Is there another possible reason for the declining interest of labour economists in trade unions? Could it be the case that economists have already said everything they usefully can about unions? The bulk of labour economists seem to think so, given the decline in published papers on this topic over the past decade since two edited volumes in the early 2000s. ${ }^{5}$ In addition, other interesting areas and methodologies have arisen, attracting researchers into less well-trodden areas where they hope to make a bigger contribution. We shall be discussing one of these alternative approaches to wage

\footnotetext{
${ }^{5}$ See Boeri, Brugiavini and Calmfors (2001) and Addison and Schnabel (2003).
} 
determination in Section 4 of this paper. But first we will briefly consider the economics of the trade union. ${ }^{6}$

\subsection{An overview of the analytical framework}

How do economists define trade unions? A trade union is an organized association of workers formed for the protection and promotion of their common interests. The standard view of unions is that they are monopoly organizations that improve the welfare of members, principally by raising wages above the competitive level. For a trade union to be able to increase wage rates above the competitive level, there must be some surplus that can be shared between the firm and the union, and the union must have some bargaining power to induce the firm to share this surplus. How can a union achieve such power? One way is to try to organize all workers in an industry, thereby acting as a monopolist over the supply of labor. ${ }^{7}$

Even if a union controls labor supply, it will not necessarily be able to negotiate a large wage increase relative to the competitive level. The magnitude of the union wage depends crucially on the elasticity of labor demand in that sector as well as union

\footnotetext{
${ }^{6}$ Readers who wish to follow a more technical exposition are referred to Booth (1995) and Cahuc and Zylberberg (2004: Chapter 7), while a European overview can be found in Boeri et al. (2001).

${ }^{7}$ The earliest successful unions were craft unions, which became established because of a combination of high demand for skilled labor during industrialization, and the control of trained labor by skilled workers through the apprenticeship system. The emergence of general or industrial unions followed a different path. During industrialization, the huge surplus of unskilled displaced agricultural labor made manipulation of labor supply impossible. A depression, coupled with a readily available pool of substitute workers, could destroy a union. To ensure survival, a general union needed political support or very high levels of membership. Obtaining the latter was difficult in the early stages of unionization, when there were no immediately obvious wages benefits because the union had not yet obtained any power. See Booth (1995).
} 
bargaining strength. There can be little doubt that, if unions emerge in competitive markets, high union wages introduce allocative inefficiencies into the economy through the distortion of factor prices. Without unions, allocative efficiency is associated with the equalization of the marginal products of identical factor inputs across sectors. With higher wages in the union sector, union firms employ fewer workers. Displaced union workers crowd into the nonunion sector, lowering wages there. As a result, too few workers are employed in the union sector where output falls, while too many workers are employed, and too many goods produced, in the nonunion sector. There is a deadweight efficiency loss, because the value of marginal products in the two sectors are not identical. In addition, there are distributional issues to consider, and longer run effects due to substitution of capital for labor. Furthermore, in unionized sectors there may be under-investment in capital through the hold-up problem (see, for example, Grout 1984).

Even within this framework, there are arguments suggesting that, in the presence of imperfect information and uncertainty, unions may enhance efficiency. To the extent that unions reduce labour turnover and negotiating costs, they may increase the available surplus to be shared between parties (Freeman and Medoff 1984). Of course, there may be interdependence between the monopoly and efficiency roles of 
trade unions: unless the union has some bargaining power, it may be unable to increase efficiency. $^{8}$

This discussion of allocative inefficiency assumes that the union has emerged in an economy characterized by competitive product and labor markets. But there is considerable evidence that, in modern industrialized countries, many product markets are characterized by imperfect competition. Moreover, nonunion firms may also face an incumbent workforce with a degree of bargaining power. Thus, even in the absence of unionization, management and workers may be in a situation of bilateral monopoly. An important question arises as to whether or not the replacement of individual bargaining by collective bargaining generates additional inefficiencies and misallocation of resources in situations where markets were previously not functioning in accordance with the textbook model of perfect competition. The majority of formal trade union models in the literature assume a perfectly competitive product market to allow the models to focus on wage and employment determination in the simplest environment. Nonetheless, it is an empirical regularity that imperfections in product and labor markets are correlated (see inter alia Stewart 1990; Dobbelaere and Mairesse, 2013).

As noted above, the existence of a potential surplus is a necessary condition for union success in its goal of improving union workers welfare. The surplus may arise from a variety of sources, the most obvious being market imperfections or regulation of the particular industry. In non-competitive firms and industries where firms are making

\footnotetext{
8 The most commonly used bargaining models for wage determination are the game theoretic approaches. These are widely used in labour economics theory regardless of the particular modelling framework.
} 
surpluses, unions with sufficient power can insist that management increases wages without threatening the demise of the firm. Thus one would expect a higher probability of union organisation in non-competitive industries than in competitive product markets.

As noted, a condition for a union to achieve wage gains is that the union has the necessary power to force the firm to share any surplus with the union; an alternative view is the firm may be willing to grant higher wages in return for increases in productivity that increase the surplus available from the firm. And although unions may cause wages to increase in the union sector, neither employment nor firm's profitability need necessarily be greatly affected, since firms higher labour costs may be offset by improved productivity. Since there are a variety of theories suggesting opposing union effect on productivity, it is ultimately an empirical issue as to whether unions are associated with increased or decreased productivity.

Next we consider an alternative approach to modelling wage determination that has captured the interest of labour economists - especially European ones - over recent years. This approach assumes that the labour market is characterized by oligopsony and monopsonistic competition. I shall use these terms interchangeably in what follows.

\section{Oligopsony in the labour market}

An intuitively appealing framework for modeling oligopsony is based on the assumption that workers with identical skills and abilities have heterogeneous preferences over the nonwage job characteristics associated with a job. What might these be? These might 
be working hours, distance of the firm from home, the people working at the firm, and the like. Bhaskar and To (1999) argued that a useful metaphor for heterogeneous preferences is in terms of the costs of travel to work (Hotelling, 1929; Salop, 1979). Of course these costs can be interpreted not only as travel costs but also as a measure of a worker's idiosyncratic preferences over job characteristic space. Hence the costs represent both physical and psychological aspects, which vary across workers and that result in some being willing to work at a particular establishment for a lower wage than at another.

\subsection{What is the evidence for oligopsony?}

The current thinking about oligopsony is based on the following incontrovertible assumptions. Not only do individuals have idiosyncratic preferences for jobs, but they also have different mobility costs and face imperfect information. Because of this, it takes time for a worker to find an alternative employer who is a perfect substitute for her current one. Moreover it is expensive for the firm to find another worker who is perfectly substitutable for his current one. This heterogeneity, coupled with mobility and search costs, imply that there are rents in the employment relationship. The larger are the rents accruing to an employer and worker from an ongoing employment relationship, the more important is imperfect competition to labour markets.

It is all very well to agree that these arguments are intuitively appealing. (And after all, they do find support in casual empiricism and one's own experiences.) But what do empirical studies have to say about heterogeneous preferences and mobility 
costs? The answer is not very much, and this is an area that would benefit from further research. While McCue and Reed (1996) provide some evidence, this is for the US, which may not be typical of other economies including those in Europe. ${ }^{9}$ Manning (2011) provides some evidence about hiring costs (see his table on page 983). To summarise, although those cover a sbroad range of estimates, hiring costs seem to be around $5 \%$ of total labour costs. Manning argues that we do not yet know enough about the hiring process, including the costs associated with hiring, and how these vary across worker types and firm types.

\section{2. A simple analytical framework}

A popular model used to capture the essence of imperfectly competitive labour markets is an equilibrium search framework. Since this is discussed extensively in Manning (2011), I will not replicate that discussion here. To a large extent it is a matter of taste which modeling framework one wants to use. I find appealing the monopsony framework as described in Bhaskar and To (1999), which provides a simpler equilibrium framework than the search theoretical approach. As noted in Booth and Coles, (2007: p1664): “Like the Nash bargaining approach, the Bhaskar and To (1999) framework implies equilibria and wage compression; that wages need not increase one-to- one with an increase in labour market productivity. The central advantage to this framework is that we need not specify matching functions, free entry conditions and so on or

\footnotetext{
${ }^{9}$ McCue and Reed (1996) utilise survey evidence in which workers were asked about their willingness to accept different low-wage jobs at various wagers and they found a significant heterogeneity in tastes.
} 
describe equilibria wage dispersion. The discussion is consequently clearer, as there are not thick market or congestion externalities to complicate matters."

Bhaskar and To (1999) simply assume that workers have idiosyncratic preferences over employment at different firms, and that those preferences are private information. Thus a firm's wage offer depends on how much he or she believes the employee prefers working there rather than elsewhere. This assumption usefully summarises the variety of reasons for imperfect competition in the labour market. ${ }^{10}$

\section{3 how does this framework help us to understand labour markets?}

How have these models of oligopsony and monopolistic competition helped us to understand labour markets? Perhaps the most analysed area in which oligopsony has improved our understanding of the labour market is minimum wages. Stigler (1946) showed that a minimum wage can increase employment under monopsony. But more realistic is the situation where there might be a few employers with market power. Bhaskar and To (1999) make an important theoretical contribution in this regard. In addition there is a whole raft of papers looking empirically at whether or not the introduction of a minimum wage will affect employment. Examples are the influential work by Card and Kruger (1994) and, in the European context, the comprehensive research by Dolado et al. (2006). Holmlund (2014, this issue) also discusses this

\footnotetext{
${ }^{10}$ The market structure is analogous to a Hotelling pricing game with at least two competing firms who differ in their nonpecuniary attributes such as location and other non-wage job characteristics. Workers have heterogeneous preferences: the more distant are the firm's characteristics from the worker's preferred characteristics the larger is the worker's disutility cost associated with employment at that firm. See also Rosen's related article on product differentiation, (Rosen, 1974).
} 
extensively. Other instances where monopoly and oligopsonistic competition have improved our understanding relate to the gender pay gap. (See Manning (2011) for a survey.)

There is an additional area in which oligopsony has increased our understanding of the workings of the labour market and this relates to the economics of work-related training. According to orthodox human capital theory, workers should always finance work-related general training. If firms were to pay for it, they would be vulnerable to the hold-up problem: the worker could simply quit after being trained, taking with her the embodied general training, and the firm would get no return to the investment.

And yet empirical evidence has demonstrated that employers do finance workrelated general training (see for instance, the findings of Booth and Bryan, 2005). In a labour market characterised by oligopsonistic wage setting, it can be shown that the associated wage compression will increase the incentive for firms to invest in general training, provided that post training productivity net of training costs is increasing in training at a faster rate than wages. Important papers in this area are by Stevens (1994), and Acemoglu and Pischke (1999a, 1999b). However, as those authors indicate, the equilibrium amount of training provided may be suboptimal from society's viewpoint. The empirical predictions of these models involving wage compression are that the firm may finance general training and that the training firm's wages will be less than the net marginal product. ${ }^{11}$

\footnotetext{
${ }^{11}$ Acemoglu and Pischke (1999a, 1999b) considered only absolute wage compression. Booth and Zoega (2004) extended their approach to consider relative wage compression and show that the latter approach encompasses a wide range of institutional arrangements and is therefore more general.
} 
Why are these models important for labour economics? Because they are able to explain survey evidence showing that firms pay for the acquisition of general training by their workforce in contradiction to what would be predicted under perfect competition. Moreover, in a study estimating the impact on training of the introduction in the UK of national minimum wage, Arulampalam et al (2004) also find evidence in support of these models. A perfectly competitive model would predict that this policy (the introduction of the national minimum wage) would reduce the training of affected workers, but these authors found evidence that training increased.

Finally, we must mention direct evidence of labour market power that can be obtained by estimating the elasticity of the labour supply curve to an individual establishment. Manning $(2003,2011)$ utilises a dynamic monopsony model based on Burdett and Mortensen (1998) to obtain a formal estimate of the elasticity of labour supply which can then be confronted with the data. Manning provides an extensive discussion of this, encompassing both the elasticity of the labour supply curve to an individual establishment as well as the sensitivity of separations. The essence of monopsonistically competitive labour markets is that labour supply to a firm is imperfectly elastic with respect to the wage rate. The intuition is that, where workers have heterogeneous preferences or face mobility costs firms can offer lower wages without immediately losing their workforce. This is in stark contrast with the perfectly competitive extreme, in which the elasticity is infinite. Monopsony suggests that the lower the ability of a worker to exploit outside options and move from job to job, the 
further will a worker's wage be below her marginal product, and the greater the share of rents that the employer can appropriate from the worker.

A simple test of whether labour markets are imperfectly or perfectly competitive involves estimating the wage elasticity of labour supply to a firm. Studies that have done this using individual level data find that wage elasticities of labour supply are typically very small (see the summary table in Manning, 1011). Indeed, these estimates of the wage elasticity of labour supply to a firm are so far from the perfectly competitive prediction of an infinite elasticity that it would be difficult to make a case that labour markets are perfectly competitive. This has implications for policy based on simplistic modeling of the labour market as perfectly competitive. It is interesting that a parallel stream of labour economics literature, focusing on employer provided training and the conditions under which firms will finance it, have reached similar conclusions.

A final example of how models of oligopsony and monopolistic competition help us to understand labour markets is in the field of education. Booth and Coles (2007) show how, in a model with heterogenous workers and home production, increasing returns to education interact with imperfectly competitive labour markets. Increasing returns to education are exacerbated by frictional labour markets because of an increasing wage competitiveness effect. This arises because, in a frictional labour market, firms bid more competitively for workers' services as the value of employment increases. And since, in frictional labour markets, wage compression decreases at higher productivity levels, the marginal returns to education are further increased as education 
increases. This has policy implications: the authors suggest an employment subsidy that could be efficiently targeted as a public childcare program.

\section{Conclusions}

A striking feature of the past twenty years since the foundation of Labour Economics has been the expansion in the development and application of models that explicitly deal with imperfectly competitive labour markets, be they based on bargaining models or models of oligopsonistic competition. These are proving to be rich avenues of research.

Another striking feature of the past twenty years has been the overall drop in interest in the economics of the trade union (although there are notable individual exceptions). I believe this is a shame, for the following reasons. First, labour markets are typically not competitive. Second, while union membership has been declining, collective bargaining coverage is far more important than density, because of institutional arrangements within Europe - and in some other OECD countries. Third, the US has unusually low density and coverage, but even there the threat of unionization imparts some relevance to the union model. Fourth, as I have suggested in this paper, labour economists' research on unions has diminished not only because of fashion but also in part because of US dominance of the academy. Labour Economics, a European-based journal, provides some counter-balance to this. It will be interesting to see what the literature looks like another twenty years hence.

Finally, should imperfectly competitive models be used whenever researchers are modelling the labour market? Some people would argue only in cases when the 
predictions and comparative statics of the imperfectly competitive model differ from those of the competitive model. Of course, to know this, one needs to know precisely what the predictions and comparative statics of the respective models are. However, there is now a growing - and some would suggest, lamentable - trend for labour economists not to use any analytical framework. The syllabuses of some labour economics courses I have seen include little about imperfectly competitive models. Moreover, atheoretic randomised experiments are increasingly being used in labour economics and represent an alternative methodology that can reveal the effect of an intervention without the need for any analytical framework. Nonetheless, for policymakers to be able to determine if an intervention is required in the first place, there does need to be some analytical framework to act as a guide. In the perfectly competitive model of the labour markets, for example, typically no intervention or regulation would be justified. However, labour economics has moved far beyond this position, with new ideas being incorporated into modeling wage determination in imperfectly competitive labour markets and with the availability of better datasets.

\section{References}

Acemoglu D., Pischke J.S., 1999a. Beyond Becker: Training in imperfect labour markets. Economic Journal. 109 (453),_, F112-F142.

Acemoglu, D., Pischke, J.S., 1999b. The structure of wages and investment in general training. Journal of Political Economy, 107, 539-72.

Addison, JT., Schnabel, C. (2003) (eds), International Handbook Of Trade Unions, Edward Elgar. 
Arulampalam, W., Booth, A.L., Bryan, M., 2004. 'Training and the New Minimum Wage', Economic Journal, 114 (494), C87-C94.

Bhaskar, V., To,T., 1999. 'Minimum Wages for Ronald McDonald Monopsonies: a Theory of Monopsonistic Competition', Economic Journal, 109 (455), 190-203.

Bhaskar, V., Manning, A., To,T., 2002. 'Oligopsony and Monopsonistic Competition in Labor Markets', Journal of Economic Perspectives, 16(2), 155-174.

Boeri, T., Brugiavini, A., Calmfors, L., (eds.) 2001. The Role of Unions in the Twenty-First Century. Oxford, UK: Oxford University Press.

Booth, A. L., 1995. The Economics of the Trade Union. Cambridge, UK: Cambridge University Press.

Booth, A. L., Bryan, M., 2005. 'Testing Some Predictions of Human Capital Theory: New Training Evidence from Britain.' Review of Economics and Statistics. LXXXVII (2) 391394.

Booth, A.L., Coles, M. G., 2007. 'A Microfoundation for Increasing Returns in Human Capital Accumulation and the Under-Participation Trap', European Economic Review. 51 (7), 1661-1681.

Booth, A.L., Zoega, G., 2004. Is wage compression a necessary condition for firmfinanced general training? Oxford Economic Papers, 56(1), 88-97.

Cahuc, P., Zylberberg, A., 2004. Collective Bargaining, in Labor Economics. Cambridge, MA: MIT Press.

Dobbelaere, S., Mairesse, J. (2013). Panel data estimates of the production function and product and labor market imperfections. Journal of Applied Econometrics, 28: 146.

Dolado, J., Kramarz, F., Machin, S., Manning, A., Margolis, D., 1996. The economic impact of minimum wages in Europe. Economic Policy, 319-

Fitzenberger, B., Kohn, K., Lembcke, A.C., 2013. Union Density and Varieties of Coverage: The Anatomy of Union Wage Effects in Germany. Industrial and Labor Relations Review.

Freeman, R. B., Medoff, J. L., 1984. What Do Unions Do? New York: Basic Books.

Grout, P. A., 1984. Investment and wages in the absence of binding contracts. Econometrica, 52(2), 449-460. 
Hotelling, D.H., 1929. Stability in competition. Economic Journal, 39 (153), 41-57.

Manning, A., 2003. Monopsony in motion: imperfect competition in labor markets. Princeton, N.J.: Princeton University Press.

Manning, A., 2011. 'Imperfect competition in the labor market', Chapter 11 in Handbook of Labor Economics, Vol 4b. 973-1041.

Marshall, A., 1920. Principles of Economics: An Introductory Volume. 8th edition, Macmillan, London.

McCue, K., Reed, W.R., 1996. New evidence on workers' willingness to pay for job attributes. Southern Economic Journal, 62(3), 647-653.

Oi, W., 1962. Labor as a quasi-fixed factor. Journal of Political Economy, 70, 538-555.

Pencavel, J., 1991. Labor Markets under Trade Unionism. Oxford, UK: Blackwell.

Robinson, J. (1933). The economics of imperfect competition. Macmillan, London.

Salop, S.C., 1979. Monopolistic competition with outside goods. Bell Journal of Economics, 10(1), 141-156.

Rosen, S., (1974). Hedonic Prices and Implicit Markets: Product Differentiation in Pure Competition. The Journal of Political Economy, 82 (1), 34-55.

Stevens, M., 1994. A theoretical model of on-the-job training with imperfect competition. Oxford Economic Papers, 46, 537-62.

Stewart, M. B., 1990. Union wage differentials, product market influences and the division of rents. Economic Journal, 100, 1122-1137.

Stigler, G., 1946. The Economics of minimum wage legislation. American Economic Review. 36, 358-365.

Visser, J., 2011. Database at: http://www.uva-aias.net/208 
Table 1: Trade Union Density and Collective Bargaining Coverage

\begin{tabular}{|c|c|c|c|c|}
\hline & \multicolumn{2}{|c|}{ Trade Union Density } & \multicolumn{2}{|c|}{ Collective Bargaining Coverage } \\
\hline & 1990 & Latest year ${ }^{i}$ & 1990 & Latest Year ${ }^{i}$ \\
\hline Australia & 39.5 & 18.0 & 80 & 40 \\
\hline Austria & 46.9 & 28.1 & 98 & 99 \\
\hline Belgium & 53.9 & 52.0 & 96 & 96 \\
\hline Canada & 34.0 & 31.6 & 38 & 31.6 \\
\hline Czech Republic & 43.5 & 17.3 & -- & 42.5 \\
\hline Denmark & 75.3 & 68.8 & 84 & 80 \\
\hline Estonia & -- & 8.0 & -- & 19 \\
\hline Finland & 72.5 & 69.9 & 81 & 90 \\
\hline France & 9.9 & 7.6 & 92 & 90 \\
\hline Germany & 31.2 & 18.5 & 72 & 62 \\
\hline Great Britain & 38.2 & 25.8 & 54 & 32.7 \\
\hline Greece & 34.1 & 24.0 & 70 & 65 \\
\hline Hungary & 49.1 & 16.8 & -- & 33.5 \\
\hline Iceland & 92.9 & 79.3 & 96.4 & 88 \\
\hline Ireland & 48.5 & 33.4 & 60 & 44 \\
\hline Italy & 38.8 & 35.1 & 83 & 80 \\
\hline Japan & 25.4 & 19.0 & 23 & 16 \\
\hline Luxembourg & 46.4 & 37.3 & 60 & 58 \\
\hline Mexico & 22.4 & 13.2 & -- & 7 \\
\hline Netherlands & 24.3 & 18.2 & 82 & 82.3 \\
\hline New Zealand & 49.5 & 20.8 & 61 & 17 \\
\hline Norway & 58.6 & 54.6 & 70 & 74 \\
\hline Portugal & 27.9 & 19.3 & 79 & 45 \\
\hline Slovakia & 64.2 & 17.2 & -- & 40 \\
\hline Spain & 12.5 & 15.9 & 82.2 & 84.4 \\
\hline Sweden & 80.0 & 67.7 & 89 & 91 \\
\hline Switzerland & 22.7 & 17.8 & 48 & 48 \\
\hline United States & 15.5 & 11.3 & 18.3 & 13.6 \\
\hline OECD & 40.1 & 28.0 & 70.3 & 62.1 \\
\hline \multicolumn{5}{|c|}{$\begin{array}{l}\text { Notes: } \\
\text { (i) 'Latest year' refers to the latest year for which data were available when searched May } 2013 . \\
\text { (ii) Data obtained from: http://www.keepeek.com/Digital-Asset- } \\
\text { Management/oecd/economics/oecd-economic-surveys-sweden-2012/trade-union-density-and- } \\
\text { collective-bargaining-coverage_eco_surveys-swe-2012-graph36-en }\end{array}$} \\
\hline
\end{tabular}

